\title{
Danish mosasaurs
}

\section{J. Lindgren ${ }^{1,2,{ }^{*}} \&$ J.W.M. Jagt ${ }^{3}$}

1 Geological Museum, University of Copenhagen, Øster Voldgade 5-7, DK-1350 København K, Denmark.

2 Department of Geology, GeoBiosphere Science Centre, Lund University, Sölvegatan 12, SE-223 62 Lund, Sweden.

3 Natuurhistorisch Museum Maastricht, de Bosquetplein 6, NL-6211 KJ Maastricht, the Netherlands.

* Corresponding author. Email: johan.lindgren@geol.lu.se

Manuscript received: September 2004; accepted: February 2005

\section{Abstract}

Presented are the first formal descriptions of mosasaur remains of Maastrichtian age from the Danish mainland (Jylland, Sjælland); just two taxa are recognised, viz. Mosasaurus cf. hoffmanni and Plioplatecarpus sp. Recent finds include an association of skeletal fragments, inclusive of a single marginal tooth crown, from within 10 metres or so of the K/T boundary near Holtug, Stevns Klint (Sjælland, eastern Denmark), here assigned to Plioplatecarpus sp. A brief review of previous records of Danish mosasaurs is added.

Keywords: Cretaceous, Maastrichtian, Denmark, Mosasaurus, Plioplatecarpus

\section{Introduction}

Despite being exceedingly rare, mosasaur remains from the Maastrichtian 'white chalks' (Skrivekridt) of Denmark are of considerable biostratigraphic significance, as they represent some of the youngest records to date of Mosasauroidea prior to their sudden, end-Cretaceous demise. Until now, the occurrence of mosasaurs in the Upper Cretaceous of Denmark has merely been hinted at, or discussed cursorily, in a small number of popular science publications.

The earliest report is that by Floris (1964, p. 26), who illustrated two isolated tooth crowns from the uppermost Maastrichtian as exposed at the 'Dania' quarry near the hamlet of Assens (northern Jylland). Unfortunately, these teeth cannot be traced now in the collections of the Geological Museum (Copenhagen), and may therefore be presumed lost. A third tooth crown (MGUH 27472), collected from (unspecified) Maastrichtian strata in an unnamed chalk pit in the vicinity of Aalborg, was later illustrated by Rasmussen (1966, p. 55). Subsequently, these three teeth have also appeared in papers by
Rasmussen (1967, fig. 121.3) and Bonde (1997a, b). Rasmussen (1967) identified them as belonging to the genus Mosasaurus, whereas Bonde (1997a, b) was more specific in his assignment and concluded that at least MGUH 27472 could be assigned to one of the larger mosasaurs of all time, Mosasaurus hoffmanni. The most recent contribution to our knowledge of Danish mosasaurs is that by Heinberg (2000), who briefly mentioned the presence of the genus Mosasaurus in the Maastrichtian white chalks of Denmark, although what he illustrated as a mosasaur vertebra (Heinberg, 2000, fig. 16) is in fact a selachian or actinopterygian vertebral centrum.

Recently, a few isolated teeth and fragmentary skeletal elements of mosasaurs have been found weathering out of a cliff face near Holtug (Stevns Klint) and in an adjacent limestone quarry (Sjælland, eastern Denmark), from within some 10 metres of the $\mathrm{K} / \mathrm{T}$ boundary there. The present contribution provides the first description of these mosasaur remains as well as the first formal account of the Aalborg specimen. 


\section{Geological setting}

The uppermost Cretaceous and lowermost Paleogene of Denmark comprise a thick sequence ( $>600 \mathrm{~m}$; see Rasmussen, 1967) of chalks and limestones deposited in a vast epicontinental sea at depths between 100 and $250 \mathrm{~m}$ (Bromley, 1979). Today, these shelf sediments crop out over large parts of the Danish mainland, although most quarries and natural outcrops are located in northern Jylland and along narrow belts following the eastern coasts of the islands of Fyn and Sjælland. The Maastrichtian grey-white chalks and limestones in Denmark are mainly of pelagic origin, comprising calcareous nanno(especially coccoliths) and microfossils (foraminifera and dinoflagellate cysts) deposited as low mounds (Bromley, 1979; see also Surlyk et al., 2003). Abundant macrofossils include bryozoans, brachiopods and echinoderms. Numerous flint nodules and flint-filled burrows testify to a palaeoenvironment with oxygenated bottom waters in which a highly diverse benthic fauna thrived. Thin beds of marl, varying from a few to several tens of centimetres in thickness, occur sporadically within the chalk facies (e.g. at 'Dania').

Age assignments rely mainly on coleoid and ammonoid cephalopods (Schulz, 1979; Birkelund, 1993; Christensen, 1996, 1997a, b; Machalski, 1996, work under way), and dinoflagellates (Schiøler \& Wilson, 1993). The highest part of the 'white chalk' and the 'grey chalk' (Gråkridt), as exposed along Stevns Klint, are of latest Maastrichtian age. Elsewhere (e.g. Møn), the sequence comprises older strata, of early Maastrichtian age (Schulz, 1979; Birkelund, 1993).

For more comprehensive descriptions of the formation and petrology of the Upper Cretaceous and lowermost Paleogene of Denmark, reference is made to Surlyk (1984) and Schmitz et al. (1992); localities referred to in the text are shown in Fig. 1.

\section{Systematic palaeontology}

Institutional abbreviations - MGUH - Geological Museum, University of Copenhagen, Copenhagen; NHMM - Natuurhistorisch Museum Maastricht, Maastricht; MNHN - Muséum National d'Histoire Naturelle, Paris.

Family Mosasauridae

Subfamily Mosasaurinae

Genus Mosasaurus Conybeare, 1822

\section{Mosasaurus cf. hoffmanni Mantell, 1829; Fig. 2}

1964 Tand af slangeøgle - Floris, p. 26.

1966 Slangeøgle - Rasmussen, p. 53.

1966 Mosasaurus Conybeare - Rasmussen, p. 55.

1967 Mosasaurus Conybeare - Rasmussen, p. 142, fig. 121.3.

1997a Mosasaurus (?) hoffmanni Mantell - Bonde, pp. 29, 30.

1997b Mosasaurus hoffmanni Mantell - Bonde, p. 13.

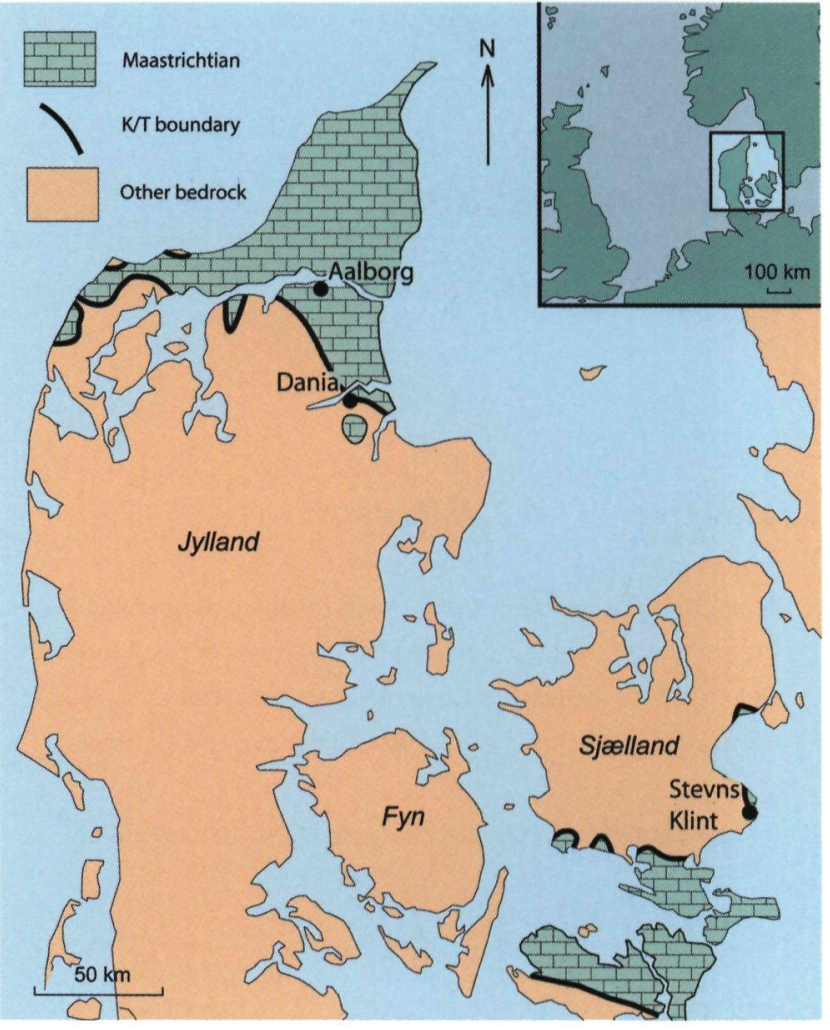

Fig. 1. Simplified map of the Danish mainland, showing the extension of the Maastrichtian white chalks and the localities mentioned in the text.

Material - MGUH 27472; a marginal tooth crown collected from lower? Maastrichtian strata near the town of Aalborg in northern Jylland, Denmark (see Håkansson \& Hansen, 1979 for a comprehensive description of the Upper Cretaceous exposed in the Aalborg area).

Description - MGUH 27472 is an isolated, presumably shed, marginal tooth crown of an adult individual assumed to have come from the mesial part of the jaw. As preserved, the sturdy crown measures $42.8 \mathrm{~mm}$ in total height (when measured at a right angle to the plane formed at the base of the crown) and $30.1 \mathrm{~mm}$ in basal width (in meso-distal direction). The original height is estimated to have been around $45 \mathrm{~mm}$. Sharp and minutely serrated carinae divide the crown into a gently convex labial face and a deeply U-shaped lingual surface. Four flattened facets are present on the labial face, giving this surface a somewhat prismatic appearance, whereas the lingual face is covered by very obscure facets. Most of the apical portion of the crown is broken off, although a shallow and elongated groove on the remaining lingual face indicates that the tip originally was heavily abraded. Another prominent furrow occupies the basal portion of the mesial face of the crown, and, in accordance with the apical one, may have been inflicted through occlusion. In basal view, the crown has a broadly elliptical outline.

Remarks - Regardless of their position in the jaw, marginal teeth of mosasaurine mosasaurs always lack a delicate surface 


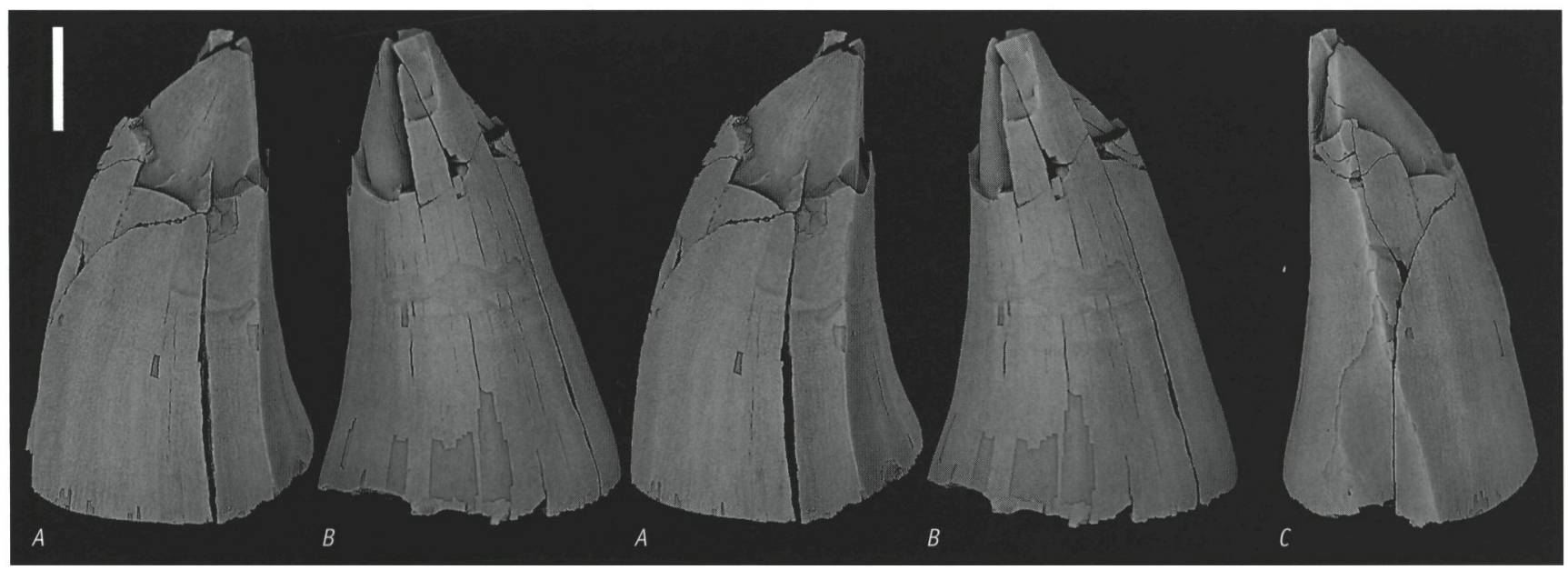

Fig. 2. Mosasaurus cf. hoffmanni Mantell, 1829 (MGUH 27472) from the lower Maastrichtian of Aalborg (Jylland, Denmark), in labial (A, stereo pair), lingual ( $B$, stereo pair) and mesial (C) view, respectively. Scale bar equals $10 \mathrm{~mm}$.

texture of closely spaced vertical striations on their lingual face, a feature typical of tylosaurines, plioplatecarpines and the enigmatic basal mosasaur Halisaurus (see Bell, 1997; Lindgren \& Siverson, 2002, 2004). A relatively low number of distinctly flattened facets on the labial face of the crown characterises teeth of the mosasaurine genera Mosasaurus and Clidastes (see Lindgren \& Siverson, 2004). However, apart from a marked difference in maximum size (in adult individuals), laterally situated marginal teeth of Mosasaurus can be readily distinguished from those of Clidastes by their unequally convex labial and lingual faces (nearly symmetrically bicarinate crowns in, at least, C. liodontus; see Lindgren \& Siverson, 2004) and finely serrated carinae (the carinae are smooth in Clidastes) (see e.g. Lingham-Soliar, 1995, fig. 15; Mulder, 1999, fig. 4; Lindgren \& Siverson, 2004, figs. 3, 4).

Currently, four nominal species of Mosasaurus from the upper Campanian and Maastrichtian of Europe, North America and North Africa are recognised as valid, namely M. hoffmanni (=M. maximus and $M$. dekayi), $M$. lemonnieri (= M. conodon; but see also Lingham-Soliar, 2000), $M$. missouriensis (= $M$. maximiliani; see Caldwell \& Bell, 2005) and $M$. beaugei (see Bardet et al., 2004). Of these species, MGUH 27472 shows the closest similarity to teeth of $M$. hoffmanni, as the crown is large and robust, and possesses flattened facets on its labial face. The moderately large (by mosasaur standards) M. lemonnieri and $M$. missouriensis have generally slender and labio-lingually compressed teeth relative to the robust and conical crowns of the giant M. hoffmanni (see e.g. Kuypers et al., 1998, pl. 2; Mulder, 1999, fig. 4.3; Machalski et al., 2003, fig. 7).

Moreover, the tooth facets in $M$. lemonnieri are commonly separated by distinct crests, resulting in concave facets, as opposed to the flattened to convex facets on the teeth of M. hoffmanni (Meijer, 1984). In M. lemonnieri, the facets are of subequal width on both surfaces, while the prisms are fewer and wider on the labial face than they are on the lingual surface on marginal teeth of $M$. hoffmanni (Machalski et al.,
2003). Recently, Bardet et al. (2004) claimed that marginal teeth of $M$. beaugei from the Maastrichtian of Morocco possess three to five labial prisms, whereas those of $M$. hoffmanni merely show two to three. However, as several $M$. hoffmanni teeth examined by us (including those in the type specimen; NMHN AC 9648) have four facets on their labial face, this statement is erroneous. Nevertheless, isolated marginal teeth of at least large individuals of $M$. hoffmanni can be separated from those of $M$. beaugei by their sturdier and labio-lingually less compressed crowns (cf. Arambourg, 1952, pl. 39, figs 13, 14, 19; Lingham-Soliar, 1995, fig. 15). Finally, it should be noted that, occasionally, teeth of $M$. hoffmanni appear to lack facets altogether, as pointed out by Kuypers et al. (1998).

Subfamily Plioplatecarpinae

Genus Plioplatecarpus Dollo, 1882

\section{Plioplatecarpus sp.; Fig. 3}

Material - MGUH DK 424; an association comprising a marginal tooth crown, an incomplete tooth base, a piece of ?sclerotic ring, and several unidentifiable skeletal fragments, presumably from a single individual, found on the shore below the cliffs near Holtug exposing uppermost Maastrichtian (Belemnella (Neobelemnella) kazimiroviensis Zone) white chalks along Stevns Klint (Sjælland, eastern Denmark).

Description - As preserved, the marginal tooth crown is $21,1 \mathrm{~mm}$ tall, and $11,0 \mathrm{~mm}$ wide. It is broken transversally across the base, exposing a capacious pulp cavity, which indicates that it probably has not been shed, but instead was detached directly from the jawbone. The tooth is strongly distally curved from about the mid-point of its height, and the enamelled faces are covered with numerous weak facets. Delicate and densely spaced striations reach a few millimetres up the base on both the lingual and labial face of the crown. Conspicuous wear 


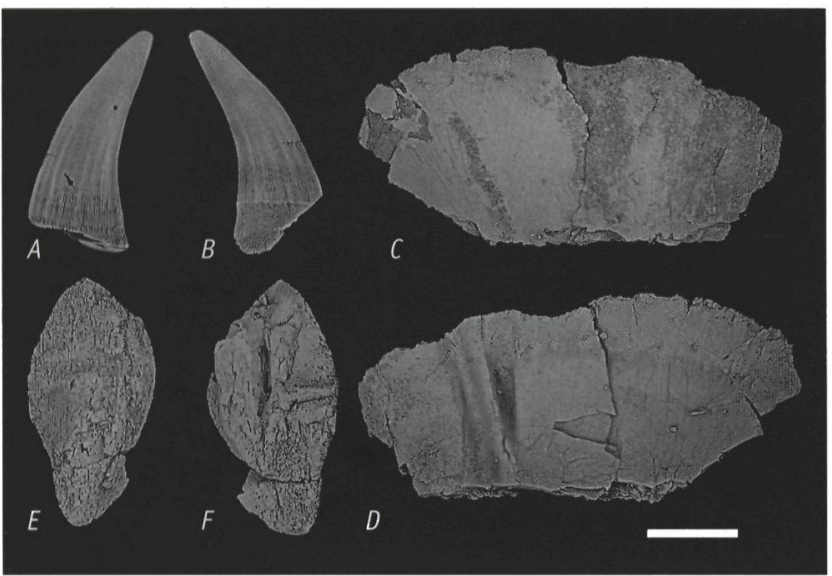

Fig. 3. Plioplatecarpus sp. (MGUH DK 424) from uppermost Maastrichtian (Belemnella (Neobelemnella) kazimiroviensis Zone; brachiopod zone 10 sensu Surlyk, 1972) strata near Holtug, Stevns Klint (Sjælland, eastern Denmark); A, B - marginal tooth crown in labial and lingual view, respectively; $C, D$ - fragment of ?sclerotic ring in lateral and medial view, respectively; $E, F$ - incomplete tooth base in lateral and medial view, respectively. Scale bar equals $10 \mathrm{~mm}$.

facets are present at the apex and along the anterior edge of the crown, whereas the posterior carina is intact and lacks serrations.

The inferred partial ?sclerotic ring comprises a very thin sheet of vaulted bone, measuring 50,6 mm in total length and 23,3 $\mathrm{mm}$ in maximum width. A few wide, indistinct grooves (and one deep depression) run perpendicular to the longitudinal axis of the bone, thus contributing to a gently undulating surface of the element.

Remarks - Isolated tooth crowns of plioplatecarpine mosasaurs can be distinguished from those of mosasaurines, tylosaurines and Halisaurus on the basis of the following character state combination: (1) fine hairline striations are present on, at least, the basal portion of the lingual face of the crowns; (2) the labial and lingual surfaces are facetted, giving the crowns a more or less prismatic appearance; (3) the carinae are prominent but rather blunt and lack serrations; (4) the crowns are more or less abruptly curved distally from about mid-height; (5) in basal view, the crowns are elliptical to subcircular; (6) the labial and lingual surfaces on at least lateral and distal teeth are of subequal convexity; and (7) the crowns are generally rather slender and slightly pointed in lateral aspect (Bengtson \& Lindgren, 2005).

The slender and abruptly distally curved nature of the marginal tooth in this new mosasaur assemblage from Stevns Klint allows a definitive generic identification, as teeth of Plioplatecarpus show a very characteristic morphology. They strongly resemble those in the dentition of the modern gavial (see Massare, 1987), and hence it is reasonable to assume that Plioplatecarpus too was adapted to piscivorous feeding. Moreover, the overall morphology of the teeth in Plioplatecarpus suggests that they had an even more pronounced piercing function than had those in the closely related genera Platecarpus and Ectenosaurus.

The dental morphology of Plioplatecarpus is closer to that of Platecarpus and Ectenosaurus than it is to any other plioplatecarpine genus, although marginal teeth of Plioplatecarpus can normally be separated from those of the two last-named genera by their more acute distal curvature, more delicate form and more pointed tips (see Williston, 1898, pl. 13; Kuypers et al., 1998, pl. 6). Furthermore, these genera are also temporally separated, as Platecarpus has been recorded from deposits spanning the middle and/or upper Turonian-lower Campanian interval (Bengtson \& Lindgren, 2005), whereas Plioplatecarpus is known only from strata post-dating the lower Campanian (Ectenosaurus is, so far, known exclusively from the upper Coniacian-lowermost Campanian Smoky Hill Chalk Member of the Niobrara Formation in western Kansas; see Russell, 1967).

\section{Miscellaneous remains and teeth in private collections}

In addition to the specimens described above, four fragments of a dorsal(?) mosasaur vertebra (MGUH V2004-348a/d) were found eighteen years ago by the skilled non-professional palaeontologist, Mrs Alice Rasmussen of Fakse, at the same locality from which she recently collected Plioplatecarpus remains (MGUH DK 424; see above). Unfortunately, the vertebra is too poorly preserved to be identified beyond family level with confidence.

Moreover, a few isolated mosasaur teeth from the Danish Maastrichtian are retained in private collections. Specimens that we know of include:

- an isolated marginal tooth crown of Plioplatecarpus and one pterygoid tooth crown, presumably assignable to Mosasaurus, from the uppermost Maastrichtian (Belemnella kazimiroviensis Zone; brachiopod zone 10 sensu Surlyk, 1972) at 'Stevns kridtbrud', close to Sigerslev. Both specimens are currently housed in the private collection of Alice Rasmussen.

- the upper portion of a fragmentary tooth crown, collected 11 June 2003 by Sylvia Verschueren, from the Thisted Kalkværk quarry, northeast of Thisted (Thy, northern Denmark), found loose on a scree slope, but apparently of late Maastrichtian age. In general habitus, this specimen matches MGUH 27472 well, in showing a deeply U-shaped lingual surface and a serrated carina. Moreover, enamel features and facetting are also comparable.

- recently, a very large marginal tooth, belonging either to Mosasaurus or to a tylosaurine, was presented to the Geological Museum (Copenhagen). This specimen was collected from a loose boulder of unknown origin, and is currently being assessed by museum staff. 


\section{Discussion}

As presently recognised, Mosasaurus hoffmanni had a wide geographical distribution during the late Maastrichtian, ranging from present-day Alabama and Missouri (US Gulf Coast) in the southwest (Kiernan, 2002; Gallagher et al., 2005), across north-central Europe and Russia (Nikolov \& Westphal, 1976; Yarkov, 1993; Tzankov et al., work under way), to Turkey in the southeast (Bardet \& Tunoğlu, 2002). In accordance with distributional patterns of marine vertebrates in the Western Interior and Gulf Coast of North America during the early Campanian (see Nicholls \& Russell, 1990), the range of $M$. hoffmanni may have been linked to palaeolatitudinal gradients (Bardet \& Pereda Suberbiola, 1996; Bardet et al., 2004). As observed by the latter authors, occurrences of M. hoffmanni are limited mainly to a palaeolatitudinal belt around $30^{\circ} \mathrm{N}$, corresponding arbitrarily to the northern margin of the Mediterranean Tethys (but see also Lingham-Soliar, 1991). If correctly identified, MGUH 27472 represents the most northerly occurrence of the species so far (around $45^{\circ} \mathrm{N}$ ), and hence extends the geographical range of that species.

There are very few mosasaur records close to the $\mathrm{K} / \mathrm{T}$ boundary from anywhere in the world, owing mainly to the general paucity of large-sized vertebrate fossils. Consequently, every single specimen is of interest, as long as reworking can be ruled out. The occurrence of Plioplatecarpus sp. in the upper part of the uppermost Maastrichtian Belemnella (Neobelemnella) kazimiroviensis Zone at Stevns Klint demonstrates that this, by all means, was one of the last mosasaurs around prior to the bolide impact event that defines the end of the Cretaceous. The same genus is also the last one to be found in situ in the Maastrichtian type area (the Netherlands; Mulder et al., 1998), and the stratigraphically youngest records comprise two pterygoid tooth crowns of Plioplatecarpus marshi (NHMM 2002003 (leg./don. A. Hofman) and NHMM 2004155 (leg./don. S. Goolaerts) collected from the higher portion of the Meerssen Member (subunits IVf-5 and f-6, Belemnella (Neobelemnella) kazimiroviensis Zone), between c. 8 and 1 metres below the $\mathrm{K} / \mathrm{T}$ boundary in the area. Thus the question arises whether mosasaurs as a group were declining in diversity prior to the profound mass extinction at the end of the Cretaceous or not. Hopefully, future in-depth stratigraphical research in Denmark, the Netherlands and other regions with suitable deposits spanning the uppermost Maastrichtianlowermost Paleogene interval, will reveal the true story behind the disappearance of these mighty marine reptiles.

\section{Acknowledgements}

JL acknowledges Kulturarvsstyrelsen (Denmark) for a research fellowship at the Geological Museum (Copenhagen). We thank Alice Rasmussen (Fakse), Dr Gilles Cuny, Bent E.K. Lindow and Sten L. Jakobsen (all Geological Museum, Copenhagen) for assistance in various ways, and André Hofman (Maastricht), Stijn Goolaerts (Katholieke Universiteit Leuven), Sylvia Verschueren and Ton Lindemann (Maarssen) for making material available to us.

\section{References}

Arambourg, C., 1952. Les vertébrés fossiles des gisements de phosphates (MarocAlgérie-Tunisie). Service Géologique au Maroc, Notes et Mémoires 92: 1-372.

Bardet, N. \& Pereda Suberbiola, X., 1996. Las faunas de reptiles marinos del Cretácico final de Europa (margen norte del Tetis mediterráneo). Revista Española de Paleontología 11: 91-99.

Bardet, N. \& Tunoğlu, C., 2002. The first mosasaur (Squamata) from the Late Cretaceous of Turkey. Journal of Vertebrate Paleontology 22: 712-715.

Bardet, N., Pereda Suberbiola, X., Iarochène, M., Bouyahyaoui, F., Bouya, B. \& Amaghzaz, M., 2004. Mosasaurus beaugei Arambourg, 1952 (Squamata, Mosasauridae) from the Late Cretaceous phosphates of Morocco. Geobios 37: 315-324.

Bell, G.L. Jr., 1997. A phylogenetic revision of North American and Adriatic Mosasauroidea. In: Callaway, J.M. \& Nicholls, E.L. (eds): Ancient Marine Reptiles. Academic Press (San Diego): 293-332.

Bengtson, P. \& Lindgren, J., 2005. First record of the mosasaur Platecarpus Cope, 1869 from South America and its systematic implications. Revista Brasileira de Paleontologia 8: 5-12.

Birkelund, T., 1993. Ammonites from the Maastrichtian White Chalk of Denmark. Bulletin of the Geological Society of Denmark 40: 33-81.

Bonde, N., 1997a. En kæmpemæssig mosasaur fra Israel. Varv 1997(1): 26-30.

Bonde, N., 1997b. Mosasaurer - et stort kranium fra Israels Øvre Kridt, samt nogle fakta om dyrene og deres marine faunaer. Geologisk Institut, Københavns Universitet (Copenhagen): 1-35.

Bromley, R.G., 1979. Chalk and bryozoan limestone: facies, sediments and depositional environments. In: Birkelund, T. \& Bromley, R.G. (eds): Cretaceous-Tertiary boundary events, I. The Maastrichtian and Danian of Denmark. University of Copenhagen (Copenhagen): 16-32.

Caldwell, M.W. \& Bell, G.L. Jr., 2005. Of German princes and North American rivers: Harlan's lost mosasaur snout rediscovered. In: Schulp, A.S. \& Jagt, J.W.M. (eds): Proceedings of the First Mosasaur Meeting. Netherlands Journal of Geosciences 84: 207-211.

Christensen, W.K., 1996. A review of the Upper Campanian and Maastrichtian belemnite biostratigraphy of Europe. Cretaceous Research 17: 751-766.

Christensen, W.K., 1997a. The Late Cretaceous belemnite family Belemnitellidae: taxonomy and evolutionary history. Bulletin of the Geological Society of Denmark 44: 59-88.

Christensen, W.K., 1997b. Palaeobiogeography and migration in the Late Cretaceous belemnite family Belemnitellidae. Acta Palaeontologica Polonica 42: 457-495.

Conybeare, W.D., 1822. Fossil crocodiles and other saurian animals. In: Parkinson, J.: Outlines of oryctology. An introduction to the study of fossil organic remains; especially those found in the British strata: intended to aid the student in his enquiries respecting the nature of fossils, and their connection with the formation of the earth 7. Printed for the author (London): 284-304. 
Dollo, L., 1882. Note sur l'ostéologie des Mosasauridæ (sic). Bulletin du Musée royal d'Histoire naturelle de Belgique 1: 55-74.

Floris, S., 1964. Slangeøgler. Varv 3: 24-26.

Gallagher, W.B., Campbell, C.E., Jagt, J.W.M. \& Mulder, E.W.A., 2005. Mosasaur (Reptilia, Squamata) material from the Cretaceous-Tertiary boundary interval in Missouri. Journal of Vertebrate Paleontology 25: 473-475

Heinberg, C., 2000. Livet i kridthavet. Varv 2000(4): 1-48.

Håkansson, E. \& Hansen, J.M., 1979. Guide to Maastrichtian and Danian boundary strata in Jylland. In: Birkelund, T. \& Bromley, R.G. (eds): Cretaceous-Tertiary boundary events, I. The Maastrichtian and Danian of Denmark. University of Copenhagen (Copenhagen): 171-210.

Kiernan, C.R., 2002. Stratigraphic distribution and habitat segregation of mosasaurs in the Upper Cretaceous of western and central Alabama, with an historical review of Alabama mosasaur discoveries. Journal of Vertebrate Paleontology 22: 91-103.

Kuypers, M.M.M., Jagt, J.W.M., Peeters, H.H.G., de Graaf, D.T., Eysermans, D., Deckers, M.J.M., Janssen, M.J. \& Arpot, L., 1998. Laat-kretaceische mosasauriers uit Luik-Limburg: nieuwe vondsten leiden tot nieuwe inzichten. Publicaties van het Natuurhistorisch Genootschap in Limburg 41: 4-47.

Lindgren, J. \& Siverson, M., 2002. Tylosaurus ivoensis: a giant mosasaur from the early Campanian of Sweden. Transactions of the Royal Society of Edinburgh, Earth Sciences 93: 73-93.

Lindgren, J. \& Siverson, M., 2004. The first record of the mosasaur Clidastes from Europe and its palaeogeographic implications. Acta Palaeontologica Polonica 49: 219-234.

Lingham-Soliar, T., 1991. Mosasaurs from the Upper Cretaceous of Niger. Palaeontology 34: 653-670.

Lingham-Soliar, T., 1995. Anatomy and functional morphology of the largest marine reptile known, Mosasaurus hoffmanni (Mosasauridae, Reptilia) from the Upper Cretaceous, upper Maastrichtian of The Netherlands. Philosophical Transactions of the Royal Society of London B347: 155-180.

Lingham-Soliar, T., 2000. The mosasaur Mosasaurus lemonnieri (Lepidosauromorpha, Squamata) from the Upper Cretaceous of Belgium and the Netherlands. Paleontological Journal 34: S225-S237.

Machalski, M., 1996. Scaphitid ammonite correlation of the Late Maastrichtian deposits in Poland and Denmark. Acta Palaeontologica Polonica 41: 369-383.

Machalski, M., Jagt, J.W.M., Dortangs, R.W., Mulder, E.W.A. \& Radwański, A. 2003. Campanian and Maastrichtian mosasaurid reptiles from central Poland. Acta Palaeontologica Polonica 48: 397-408.

Mantell, G., 1829. A tabular arrangement of the organic remains of the County of Sussex. Transactions of the Geological Society of London (2)3: 201-216.

Massare, J.A., 1987. Tooth morphology and prey preference of Mesozoic marine reptiles. Journal of Vertebrate Paleontology 7: 121-137.

Meijer, A.W.F., 1984. Tanden van Mosasaurus lemonnieri Dollo, 1889 (Reptilia, Mosasauridae) in Limburgse Krijtafzettingen. Natuurhistorisch Maandblad 73: $146-148$

Mulder, E.W.A., 1999: Transatlantic latest Cretaceous mosasaurs (Reptilia, Lacertilia) from the Maastrichtian type area and New Jersey. Geologie en Mijnbouw 78: 281-300.

Mulder, E.W.A., Jagt, J.W.M., Kuypers, M.M.M., Peeters, H.H.G. \& Rompen, P., 1998. Preliminary observations on the stratigraphic distribution of Late Cretaceous marine and terrestrial reptiles from the Maastrichtian type area (SE Netherlands, NE Belgium). Oryctos 1: 55-64.
Nicholls, E.L. \& Russell, A.P., 1990. Paleobiogeography of the Cretaceous Western Interior Seaway of North America: the vertebrate evidence. Palaeogeography, Palaeoclimatology, Palaeoecology 79: 149-169.

Nikolov, I. \& Westphal, F., 1976. Mosasaurier-Funde aus der Oberkreide von Nordwest-Bulgarien. Neues Jahrbuch für Geologie und Paläontologie, Monatshefte 1976: 608-613.

Rasmussen, H.W., 1966. Danmarks geologi. Gjellerup Forlag (København): 174 pp. Rasmussen, H.W., 1967. Blottede lag fra Danmarks underground - skrivekridtet. In: Böcher, T.W., Schou, A. \& Volsøe, H. (eds): Danmarks Natur, 1: Landsabernes 0pstáen. Politikens Forlag (København): 131-160.

Russell, D.A., 1967. Systematics and morphology of American mosasaurs (Reptilia, Sauria). Peabody Museum of Natural History, Yale University, Bulletin 23: 1-241.

Schiøler, P. \& Wilson, G.J., 1993. Maastrichtian dinoflagellate zonation in the Dan Field, Danish North Sea. Review of Palaeobotany and Palynology 78: 321-351.

Schmitz, B., Keller, G. \& Stenvall, O., 1992. Stable isotope and foraminiferal changes across the Cretaceous-Tertiary boundary at Stevns Klint, Denmark: Arguments for long-term oceanic instability before and after bolide-impact event. Palaeogeography, Palaeoclimatology, Palaeoecology 96: 233-260.

Schulz, M.-G., 1979. Morphometrisch-variationsstatistische Untersuchungen zur Phylogenie der Belemniten-Gattung Belemnella im Untermaastricht NWEuropas. Geologisches Jahrbuch A47: 3-157.

Surlyk, F., 1972. Morphological adaptations and population structures of the Danish Chalk brachiopods (Maastrichtian, Upper Cretaceous). Det Kongelige Danske Videnskabernes Selskab, Biologiske Skrifter 19: 1-57.

Surlyk, F., 1984. The Maastrichtian stage in NW Europe, and its brachiopod zonation. Bulletin of the Geological Society of Denmark 33: 217-223.

Surlyk, F., Dons, T., Clausen, C.K. \& Higham, J., 2003. Upper Cretaceous. In: Evans, D., Graham, C., Armour, A. \& Bathurst, P. (eds): The Millennium Atlas: petroleum geology of the central and northern North Sea. Geological Society of London (London): 213-233.

Williston, S.W., 1898. Mosasaurs. In: Williston, S.W. (ed.): Paleontology, Part 1, Upper Cretaceous. The University Geological Survey of Kansas 4: 81-347.

Yarkov, A.A., 1993. History of a study of mosasaurs in Russia and some aspects of their taxonomy. Voprosy Stratigrafii Paleozoia, Mezozoia i Kainozoia 7: 26-40. 